\title{
ONE STAGE CORRECTION OF CONGENITAL COMPLEX PENILE CURVATURE BY COMBINED MODIFIED NESBIT'S PROCEDURE WITH DORSAL DARTOS FLAP
}

\author{
By \\ Mohamed Shahin and Mohamed Ramadan Rehan* \\ Department of Surgery (pediatric surgery unit) and Urology،* Faculty of Medicine, Al- \\ Azhar University
}

\begin{abstract}
Background: Congenital complex penile curvature (CCPC) is a rare deformity that arises from asymmetry of the corpora cavernosa. Congenital complex penile curvature has two abnormality components: torsion and curvature of the penis either ventral or dorsal.
\end{abstract}

Objectives: Evaluation of one stage correction of CCPC by combination of modified Nesbit's procedure with dorsal dartos flap.

Patients and Methods: This prospective study was conducted at Al-Azhar University Hospital in Damietta. Twenty eight patients with CCPC were evaluated and corrected during the period from October 2014 to September 2017. Their mean age was 5.5 \pm 2.1 years (range 2-9.5 y). The direction of mal-rotation was anticlockwise in 23 patients and clockwise in 5 patients. Fifteen cases have ventral curvature; 8 cases have dorsal curvature, while 5 cases have lateral curvature. All cases were treated firstly by modified Nesbit's procedure for correction of chordee, and then dorsal dartos flap was used for correction of penile mal-rotation in one stage.

Results: All patients were corrected with high success rate. There were no more than $10^{\circ}$ of residual malrotation or binding in all patients. One patient (3.57\%) had penile hematoma that treated conservatively. All patients and their parents were satisfied with wonderful cosmetic and functional outcomes with no recurrent mal-rotation or binding. All cases were followed up for a mean follow up period of $9 \pm 1.7$ months (range 6 $12 \mathrm{~m}$. .).

Conclusion: Congenital complex penile curvature can be treated in one-stage surgery with excellent cosmetic and functional outcomes by combination of modified Nesbit's procedure with dorsal dartos flap.

Key words: Penile curvature, penile torsion, plication, tunica albuginea, congenital.

\section{INTRODUCTION}

Penile torsion is a rotational anomaly of the penile shaft. Surgical procedures for correction of penile torsion vary from degloving the penis and repositioning of the skin to more complex technique sinvolving the corporal tissue (Abou Zeid and Soliman, 2010). If the penile torsion is less than 20-30 degrees, surgical correction is not considered (Snow 2009). 
Congenital complex penile curvature (CCPC) has two deformity components: torsion and curvature of the penile shaft with no restricting fibrous band or congenital short urethra as found in chordee without hypospadias (Montag and Palmer 2011).

There are few reports of the treatment of congenital complex penile curvature in the literature as penile shaft skin rotation, suturing the tunica albuginea to the periosteum of the pubis, dorsal dartos flap rotation, Nesbit plication or $\mathrm{U}$ shaped plication (Snow 2009).

In our study, the congenital complex penile curvature was corrected in one stage, firstly by modified Nesbit's procedure (incision plication corporoplasty) for correction of curvature, and then dorsal dartos flap was used for correction of penile mal-rotation.

\section{PATIENTS AND METHODS}

Twenty eight patients with CCPC were evaluated and corrected from October 2014 to September 2017at Pediatric Surgical Unit and Urology Department, Al-Azhar University Hospital in Damietta. Their mean age was $5.5 \pm 2.1$ years (range2-9.5 y). Various degrees (30-90 ${ }^{\circ}$ ) of penile curvature were associated with $30^{\circ}-90^{\circ}$ penile rotation. Pre-and postoperative assessment of penile torsion was done by using the orthotopic meatus as a guide to determine the degree of rotation. Also, the angle of penile rotation was measured on the photograph, using MicroDICOM viewer program for image analysis, based on the orientation of the urethral meatus relative to the vertical position (Fig.1).

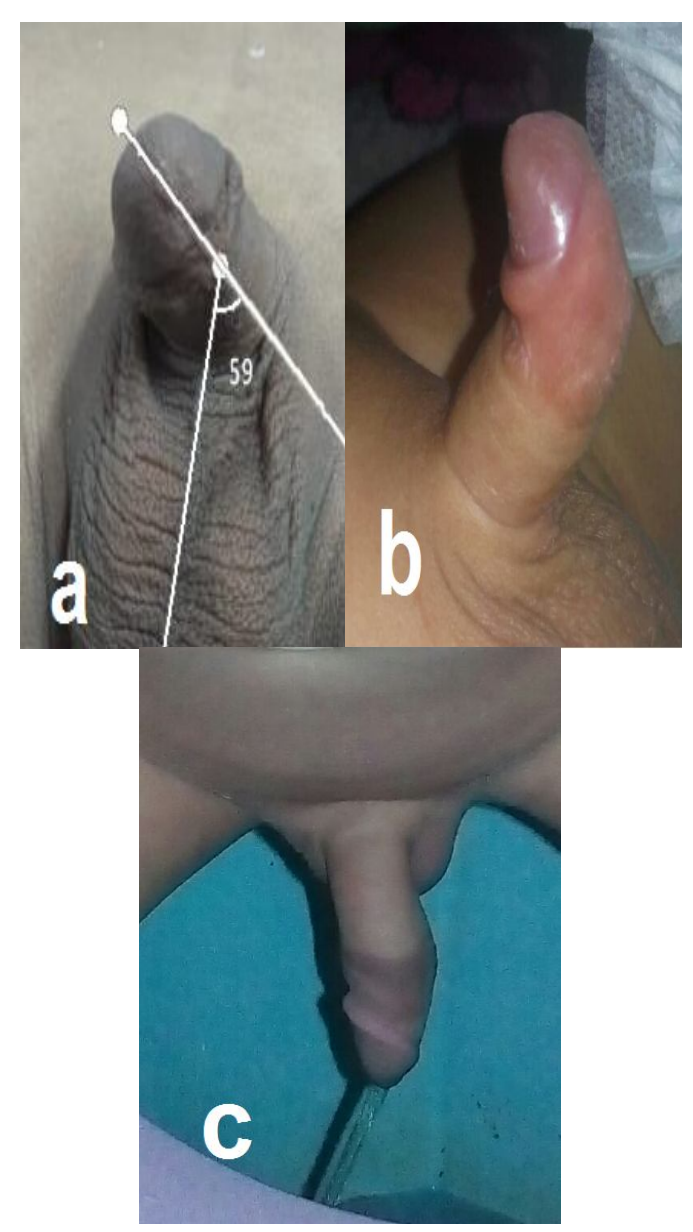

Figure (1) (a.): The angle of penile rotation was measured on the photograph, using Micro DICOM viewer program for image analysis.

(b.): A case of dorsal curvature $90^{\circ}$ with counterclockwise $30^{\circ}$ rotation.

(c.): A case of lateral curvature $60^{\circ}$ with counterclockwise $45^{\circ}$ rotation.

The direction of mal-rotation was anticlockwise in 23 patients and clockwise in 5 patients. Fifteen cases had ventral curvature, 8 cases had dorsal curvature, while 5 cases had lateral curvature (Table 1). All cases were treated in one stage by modified Nesbit's procedure for correction of penile curvature, followed by dorsal dartos flap for correction of penile malrotation. All cases were followed up for a 
mean follow up period of $9 \pm 1.7$ months (range $6-12 \mathrm{~m}$.).

The study protocol was approved by local research and ethics committee of $\mathrm{Al}$ Azhar Faculty of Medicine; the study protocol was explained to all guardians and their informed consents for participation in the study were obtained. Confidentiality and the right to withdraw from the study at any point of time were guaranteed.

\section{Operative technique:}

A circumferential sub-coronal incision of the prepuce was first performed and the phallus was degloved. The overlying skin was retracted toward the penile base in standard fashion by division of the adhesions along the entire penile shaft. After restriction of the penile base with a rubber band, the correction was demonstrated after inducing an artificial erection by injection of normal saline through a scalp vein needle which previously inserted into the glans penis or penile shaft. Penile deformity was inspected carefully (Fig. 2a.). Penile curvature was identified immediately and the orientation of the urethral meatus was used as a reference to determine the direction and degree of penile torsion

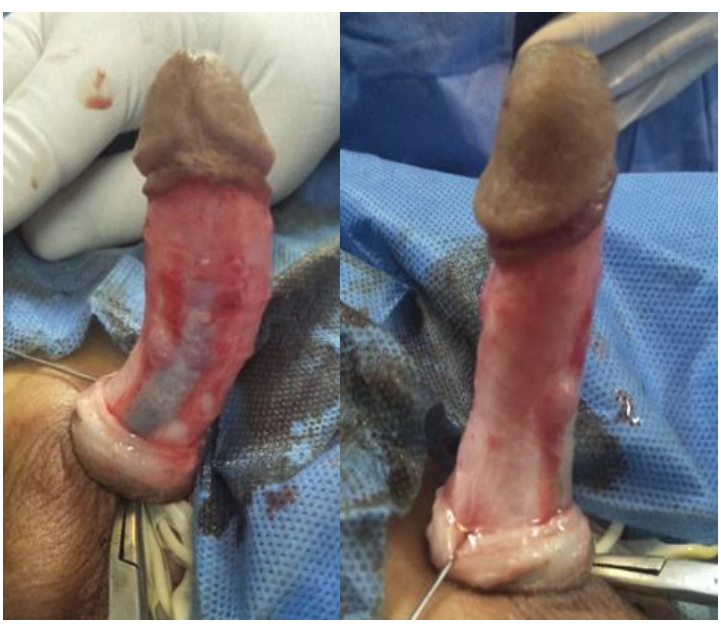

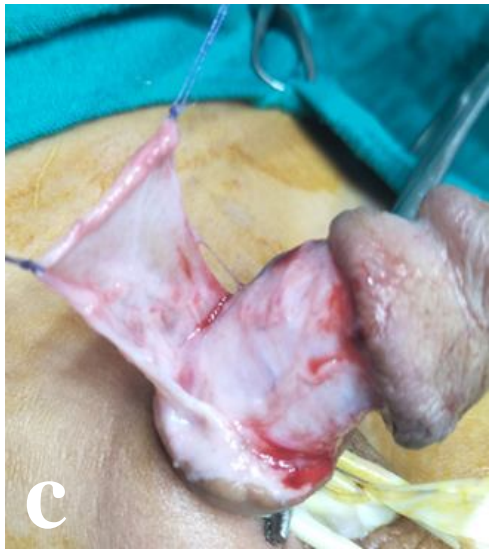

Figure (2) (a.): Penile curvature was identified after an artificial erection.

(b.): An artificial erection after Modified Nesbit's technique.

(c.): Dosal dartos flap prepared for rotation around the side of penile shaft opposite to the direction of penile torsion.

The tunica albuginea at those locations were incised and sutured transversely with PDS 3/0 and the knots were buried inside of the incisions. An artificial erection was done again to ensure complete correction of penile curvature. With persistence of torsion, additional plicating sutures were added. The sutures were kept long enough for scarring to take place before the sutures lost their tension. The neurovascular bundle complex and urethra were preserved and avoided from iatrogenic injury by placement of plicating sutures lateral to it.

The dorsal dartos flap, after its dissection from the dorsal penile skin, was rotated around the side of the penile shaft opposite to the direction of torsion and attached to its ventral aspect. A rotational force was created which counter-balanced the penile torsion (Fig. 2c.). 
Skin repositioning was done to bring the twisted median raphe to its straight direction. Finally, the wound was closed with 5-0 vicryl, and the penis was wrapped for 3 days.

Examination for palpable suture knot along the shaft was performed by a doctor who was blind to the operative procedure. Furthermore, the patient was questioned about sensation of the knot which bothered him. However, the patient words were used for assortment of cases with palpable suture knot.
Parents' satisfaction about cosmetic results of the technique was evaluated using a subjective score ranging from $0-4$ where; $0=$ no satisfaction, 1 = fair satisfaction, 2 = good satisfaction, $3=$ very good satisfaction and 4 $=$ excellent satisfaction.

Statistical Analysis: Data were summarized by mean \pm standard deviation and categorical variables were expressed as percentage $(\%)$.

\section{RESULTS}

The mean operative time was $35 \pm 17$ minutes (range 27-52 min.). Dressing of two patients $(7.14 \%)$ was soaked with blood which stopped spontaneously within 24 hours. The post-operative hospital stay was $4 \pm 1.8$ days (range 3-7 d.) depending on the age of the patient and the penile edema (Table 2). All patients were recorded photographically before and after surgery for follow-up and cosmetic evaluation.

After surgical correction, all patients had straightened erect penis with excellent cosmetic results according to parent's satisfaction, clinical evaluation and photographic measurement. Mild penile edema was acceptable (Fig. 3). One patient $(3.57 \%)$ had penile hematoma which was treated conservatively. The remaining angles of penile torsion and curvature were less than $10^{\circ}$. No recurrence of curvature or mal-rotation was reported (Table 3 ). The mean postoperative period of follow-up was $9 \pm 1.7$ months (range: 6-12 months). 

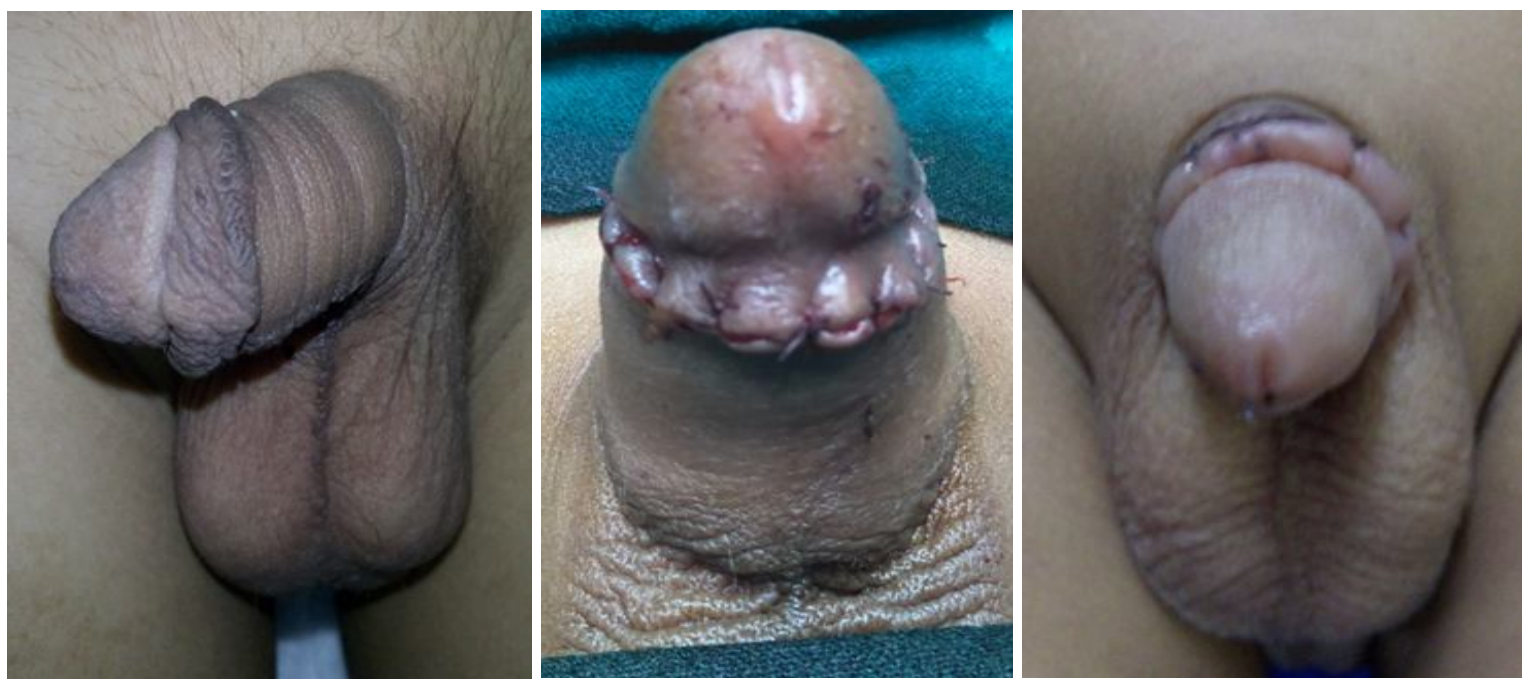

Figure (3): Pre- and early post-operative excellent straight penis and vertical mid-line slit-like urethral meatus.

Table (1): Patient characteristics in the studied population

\begin{tabular}{|c|c|c|c|}
\hline \multirow{2}{|c|}{ Parameters } & No. of cases & Percentage \\
\hline \multirow{2}{*}{ Penile rotation } & Anticlockwise & 23 patients & $82.14 \%$ \\
\cline { 2 - 4 } & Clockwise & 5 patients & $17.86 \%$ \\
\hline \multirow{3}{*}{ Penile curvature } & Ventral Curvature & 8 patients & $28.5 \%$ \\
\cline { 2 - 4 } & Lateral Curvature & 5 patients & $18 \%$ \\
\cline { 2 - 4 } & Dorsal Curvature & 15 patients & $53.5 \%$ \\
\hline
\end{tabular}

Table (2): Perioperative parameters in the studied population

\begin{tabular}{|c|c|c|c|}
\hline Parameters & Minimum & Maximum & Mean \pm SD \\
\hline Mean age (years) & 2 & 9.5 & $5.5 \pm 2.1$ \\
\hline Operative time (minutes) & 27 & 52 & $35 \pm 17$ \\
\hline Mean postoperative hospital stay (days) & 3 & 7 & $4 \pm 1.8$ \\
\hline Mean follow-up (months) & 6 & 12 & $9 \pm 1.7$ \\
\hline
\end{tabular}

Table (3): Post-operative complications

\begin{tabular}{|c|c|c|}
\hline Complications & No. of patients. & Percentage \\
\hline Dressing soaked with blood & 2 & $(7.14 \%)$ \\
\hline Hematoma & 1 & $(3.57 \%)$ \\
\hline Functional and aesthetic impairment & 0 & $(0 \%)$ \\
\hline Residual curvature or malrotation & 0 & $(0 \%)$ \\
\hline Skin ischemia & 0 & $(0 \%)$ \\
\hline
\end{tabular}




\section{DISCUSSION}

Some authors proposed the way to correct congenital complex penile curvature is to divide the anomaly into two components (torsion and curvature), and then to correct them stepwise. The first step of the correction is untwisting of penile torsion, then the remaining penile curvature, either ventral or lateral, can be handled with ease by applying an extra plication on the maximally convex area and a straightened penis is ensured (Hsieh et al., 2012).

In our study, the congenital complex penile curvature was corrected in one stage, firstly by modified Nesbit's procedure for correction of curvature, and then dorsal dartos flap was used for correction of penile mal-rotation. All patients (28 cases) had straightened erect penis with accepted cosmetic results. One patient had penile hematoma which was treated conservatively. The remaining angles of penile torsion and curvature were less than $10^{\circ}$. No recurrence of curvature or mal-rotation was reported. One stage correction provided high success rate, one stage; smooth handling of healthy tissues with less exposure to surgical and anesthetic trauma.

The first operation to correct penile curvature was described by (Nesbit, 1965). It consists of simple plication of the albuginea with a running nondissolvable suture on the convex side of the curvature. A modified version, Nesbit II entails excision of an ellipse of albuginea on the convex aspect of the penis at the site of major bending of the corpora cavernosa, so as to shorten the convexity and correct the curvature. This technique involves circumcision and complete degloving of the penis (Alei et al., 2014).

In our study, incision plication corporoplasty was used as a modifications of the Nesbit's procedure instead of excision of tunica albuginea, tunica shaving and intra-tunical suturing using absorbable suture materials, all of which aimed to reducing the incidence of complications as hypoesthesia of glans and penile shaft, suture granuloma, over correction, bulging or shortening of the penis and erectile dysfunction.

(Austoni et al., 1993) corrected complex penile curvature by resuspending the ipsilateral suspensory ligament of the penis to restore the true axis. Their methods may serve well to treat simple congenital malrotation of the penis in children but will not effectively correct the rotated corporal bodies with curvature in a well-developed penis. Their methods may serve well to treat simple congenital malrotation of the penis in children but will not effectively correct the rotated corporal bodies with curvature in a welldeveloped penis (Hsieh et al., 2012).

(Bhat et al., 2014) concluded that, the technique of distal mobilization of a hypoplastic urethra with spongiosum from the corpora into the glans, and proximally up to the bulbar region corrects moderate to severe chordee and torsion without hypospadias with excellent cosmetic results. All patients had excellent functional and cosmetic results. No residual chordee or torque was observed in any patient on follow-up at 12-24 months.

We suggested that, this procedure is suitable in mild cases as in skin chordee or fibrotic fascia (dartos and Buck's), while 
in corporal disproportion or congenital short urethra it will be insufficient.

(Hsieh et al., 2012) described a procedure to correct congenital penile curvature with multiple plications of the tunica albuginea (3-5 sutures), One patient reported a mild sensory impairment of the penile skin that resolved 2 months later.

Tunical corporoplasty and tunical plication are two techniques used to correct penile curvature. In tunical corporoplasty, permanent fusion of the tunical margins by the healing process adds more strength of the sutures and allow for much better results in terms of recurrence. However, the invasive corporoplasty and the longtime of tourniquet may be harmful to the sensory nerves and the erectile tissue (Perdzyński and Adamek, 2015).

On the contrary, tunical plication procedures are less invasiveand separation of dorsal neuro-vascular bundles from the tunica albuginea is not done in plication technique (Ahmadnia et al., 2016). However, in plication, the strength depends only on the sutures and not on the healing process (Kuehhas and Egydio, 2012). After tunical plication, the recurrences rates were high (Leonardo et al., 2012 and Vicini et al., 2016) and the presence of permanent palpable knots at the site of the tunical sutures were noted causing discomfort or even pain (Chen et al., 2016).

(Salem et al., 2009) stated that, tunica albuginea plication technique is simple and not time consuming. It prevents the complications of dissection and mobilization of the neurovascular bundles. Slight shortening of the penis is a disadvantage of the technique. Successful outcome was achieved in $19(95 \%)$ of 20 patients treated with tunica albuginea plication. No patient complained of significant shortening of the erect penis. Recurrence of curvature occurred in 1 patient. Three patients complained of uncomfortable sensation due to palpable knots from the polypropylene sutures. One patient had corrective surgery by stitch removal under local anesthesia with no recurrence of the curvature.

Penile torsion $\left(30-180^{\circ}\right)$ was repaired over a 4-year period, on a ladder step basis irrespective of the degree of torsion, starting with degloving and skin realignment, then a dorsal dartos flap and finally corporopexy. The torsion was checked with artificial erection after each step, if corrected completely the next step(s) was omitted. Postoperative complications included 5 cases of penile edema, 1 case of hematoma and 1 case of dorsal skin gangrene. Residual torsion of $<15^{\circ}$ occurred in 3 cases. No cases required redo surgery (Elbatarny and Ismail, 2014).

The preferred approach by (Perdzyńskiand Adamek, 2015) was through longitudinal skin and tunica dartos incisions over the convex surface of penis which decreases invasiveness (degloving is not necessary) as well as enables preservation of the foreskin. In ventral curvatures, the authors prefer to perform local (as short and as narrow as possible) elevation instead of complete separation of both neuro-vascular bundle from tunica albuginea, which is additional measure for decreasing intra-operative injury.

Most of authors as well as in this study, used a circumferential sub-coronal 
incision and penile degloving for penile straightening (Nyirady et al., 2008).

(Hsieh et al., 2012) stated that (Belgrano et al., 2000) proposed an asymmetrical, racket-shape excision of tunica albuginea for correction of complex penile curvature. They applied two different sizes of Allis clamps on the longer part of the tunica albuginea to delineate the maximum area for excision. Practically, it is difficult to assess the exact area for resection as a racket-shape.

(Abdel Hameedand El Gamal, 2018) concluded that, correction of penile torsion by using dorsal dartos flap rotation or by suturing tunica albuginea to the pubic periosteum is satisfactory with good cosmotic result in all patients. However the former technique is much easier to perform than suturing the corpora to the periosteum of the pubis, which requires much more dissection.

Shaeer's corporal rotation enables correction of any degree of ventral congenital penile curvature, with minimal narrowing and penile shortening. Shaeer III is a non-corporotomy technique in which the corpora are rotated using permanent suture material for approximation, without the dorsal incisions of Shaeer I and II. Shaeer III is less invasive and has addressed the drawbacks of the former techniques (Shaeer and Shaeer, 2016).

(Snow, 2009) recommended that the congenital penile torsion can be corrected by degloving first and performing an artificial erection if only skin and dartos are involved with the torsion, the common over-rotation of the skin can be used to complete the penile detorsion procedure. If the erection demonstrate persistent penile torsion, diagonal corporal plication suture is much easier to perform than suturing the corpora to the periosteum of the pubis, which requires much more dissection and has been very effective results.

In most reports, the method of measuring the degree of penile torsion is not clarified. (Pierrot and Muthurajan, 2007) described a method using a sterile small protractor with modification for a better adjustment around the penile shaft (Abou Zeid and Soliman, 2010). Torsion may be classified as mild $\left(<45^{\circ}\right)$, moderate $\left(45-90^{\circ}\right)$ or severe $\left(>90^{\circ}\right)$ degree depending upon the degree of rotation of median raphe from midline.

In this study, we introduced both simple and objective method to measure the degree of penile torsion. The angle of rotation was measured on a digital end-on photograph of the penis, using a software program for image analysis. The angle of penile rotation was measured on the photograph, using MicroDICOM viewer program for image analysis, based on the orientation of the urethral groove (meatus) relative to the vertical position. This can be applied both pre- and post-operatively providing an objective evaluation of the corrective surgery.

For penile torsion associating hypospadias, the dorsal dartos flap can have the dual benefit of correcting penile rotation and providing vascular tissue support to the urethroplasty. To avoid the risk of under or over correction, the amount of flap rotation should be determined with respect to the degree of torsion, and still some final adjustments should be made during skin closure (Abou Zeid and Soliman, 2010). 
Satisfactory results in $95 \%$ of patients with isolated penile torsion with rotation $<90$ degrees were acheived using a simple technique of penile degloving and realignment (Ozturk and Ozturk, 2014). In children with higher degrees of torsion (>90 degrees) or torsion associated with hypospadias, the use of a dorsal rotational dartos flap may help to correct the defect (Montag and Palmer, 2011).

\section{CONCLUSION}

Congenital complex penile curvature can be treated in one-stage surgery with excellent cosmetic and functional outcomes by combination of modified Nesbit's procedure with dorsal dartos flap.

\section{CONFLICT OF INTEREST}

None of the contributing authors have any conflict of interest, including specific financial interests or relationships and affiliations relevant to the subject matter or materials discussed in the manuscript.

\section{REFERENCES}

1. Abdel Hameed H and El Gamal S (2018): Dorsal dartos flap Rotation Versus suturing tunica albuginea to the pubic periosteum for Correction of Penile torsion: A prospective Randomized Study - Egyptian Urological Association. 5 (12):33-40.

2. Abou Zeid A A and Soliman H (2010): Penile Torsion: an Overlooked Anomaly with Distal Hypospadias. Annals of Pediatric Surgery, 6(2), 93-7.

3. Ahmadnia H, Kamalati A, Younesi Rostami M, Imani MM, Asadpour AA and Hariri MK. (2016): The Therapeutic Effects of Intracavernosal Plaque Excision in Peyronie's Disease: A None Grafting or Tunical Excising Procedure. World J Plast Surg., 5:62-6.

4. Alei G, Letizia P, Alei L, Massoni F and Ricci S. (2014): New surgical technique for ventral penile curvature without circumcision BJU Int., 113: 968-74.
5. Austoni E et al. (1993):C.F. Hsieh et al. (2012).

6. Belgrano et al. (2000):C.F. Hsieh et al. (2012).

7. Bhat A, Sabharwal K, Bhat M, Singla M, Kumar V, Upadhyay R.(2014): Correction of penile torsion and chordee by mobilization of urethra with spongiosum in chordee without hypospadias. J Pediatr Urol., 10(6):1238-43.

8. Chen R, Mc Craw C and Lewis R. (2016): Plication procedures-excisional and incisional corporoplasty and imbrication for Peyronie's disease. Transl Androl Urol , 5:318-33.

9. Elbatarny AM and Ismail KA, (2014): penile torsion repair in children following a ladder step: simpler steps are usually sufficient.J Pediatr Urol., 10(6):1187-92.

10. Hsieh J T, WongW Y, Chang H J, Chen J, and Liu S P.(2012): one-stage correction of congenital complex penile curvature by tunica albuginea plications. J Formos Med Assoc., 101:416-20.

11. Kuehhas FE and Egydio PH. (2012): Superficial tunica albuginea excision, using geometric principles, for the correction of congenital penile curvature. BJU Int., 110:E949-53.

12. Leonardo $C$, De Nunzio $C$, Michetti $P$, Tartaglia N, Tubaro A and De Dominicis C, (2012): Plication corporoplasty versus Nesbit operation for the correction of congenital penile curvature. A long-term follow-up. Int Urol Nephrol., 44:55-60.

13. Montag $S$ and Palmer $L$ S. (2011): Abnormalities of Penile Curvature: Chordee and Penile Torsion. The Scientific World Journal, 11; 1470-8.

14. Nesbit (1965): C. F. Alei et al. (2014).

15. Nyir?dy P, Kelemen Z, B?nfi G, Rusz A, Majoros $A$ and Romics I. (2008): Management of congenital penile curvature. J Urol., 179:1495-8.

16. Ozturk H and Ozturk S. (2014): Penile rotation and penoscrotal transposition associated with hypospadias and bifid scrotum: A case report, Ped Urol Case Rep.,1(5):5-9. 
17. Perdzyński W and Adamek M. (2015): A new corporoplasty based on stratified structure of tunica albuginea for the treatment of congenital penile curvature - long-term results. Cent. European J Urol., 68:102-8.

18. Pierrot $S$ and Muthurajan S. (2007): C.F.Abou Zeid A A and Soliman H (2010)

19. SalemT., Elbakry A. and Al Attrash G. (2009): Simplified Approach for Correction of Congenital Penile Curvature. Uro Today Int J., 2(5): 102-6.

20. Shaeer O and Shaeer K.(2016): Shaeer's Corporal Rotation III: Shortening-Free Correction of Congenital Penile Curvature-
The Noncorporotomy Technique Euro urology, 6:(9):129-34

21. Snow B W (2009): Penile torsion correction by diagonal corporal plication sutures. International Braz J Urol.:35 (1): 56-9.

22. Vicini P, Di Nicola $S$, Antonini G, De Berardinis E, Gentile $V$ and De Marco F. (2016): Geometrical modified nesbit corporoplasty to correct different types of penile curvature: description of the surgical procedure based on geometrical principles and long-term results. Int J Impot Res., 28:209-15. 


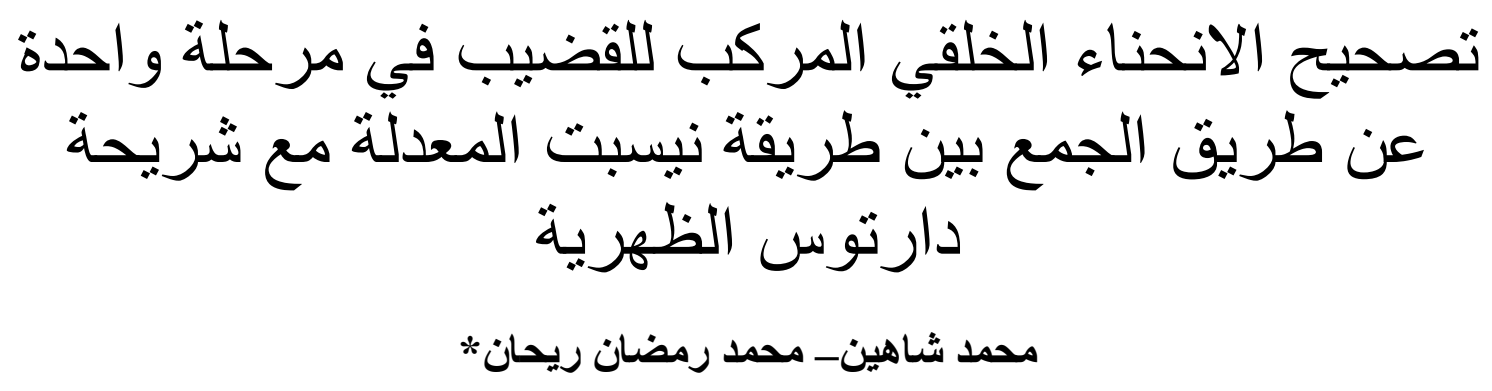

قسمي الجراحة العامة (وحدة جراحة الأطفال)، وجراحة المسالك البولية** ـ كلية الطب، جامعة الأزهر

خلفية البحث : يالانحناء الخلقي المركب للقضيب هو تشوه نـادر ينشـأ من عدم التماثل في النسيج الإسفنجي. و انحنـاء القضيب الخلقي المركب له مكونـان غير طبيعيين: الالتواء و انحنـاء القضيب (بطني أو ظهري أو لون جانبي).

الهدف من البحث: تقييم تصحيح الانحناء الخلقي المركب للقضيب من مرحلة واحدة عن طريق الجمع بين طريقة نيسبت المعدلة مع شريحة دارتوس الظهرية.

المرضي و طرق البحث: تم تقييم ^Y مريضـا بعيب الانحنـاء الخلقي المركب للقضيب وتصحيحها في الفترة

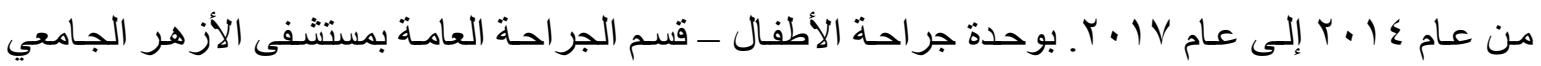

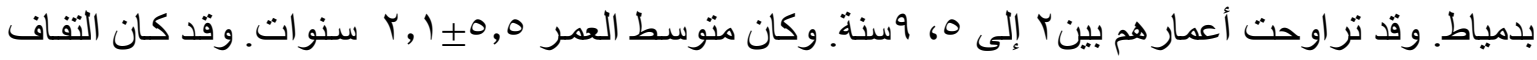
القضيب في بr مريضا عكس اتجاه عقارب الساعة، وخمس حالات في نفس اتجاه عقارب السـاعة. وقد كان الانحناء البطني موجودا في 10 حالة، الانحناء الظهري في ^ حالات، في حين كان الانحناء الجانبي موجودا في 0 حالات. و وقد تم علاج جميع الحالات أولاً عن طريق إجر اء طريقة نيسبت المعدلة لتصحيح الانحناء، ثم تم استخدام شريحة دارتوس الظهرية لتصحيح التفاف القضيب في مرحلة واحدة.

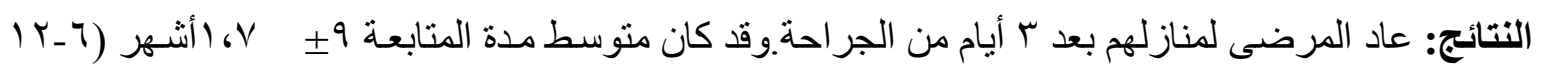
شهر). وقد حدث لمريض واحد (7، \%\%) تجمع دموي وتم شفاؤه بالعلاج دون تدخل جر احي. وقد تم تصحيح

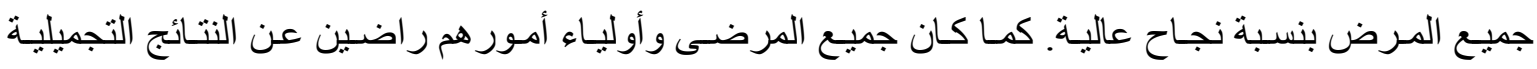
والوظيفية بدون انحناء أو التفاف مرتجع.

الاستنتاج: يمكن تصحيح الانحنـاء الخلقي المركب للقضيب في مرحلة واحدة عن طريق الجمع بين إجراء طريقة نيسبت المعدلة مع شريحة دارتوس الظهرية بنتائج تجميلية ووظيفية ممتازة. 